Murmúrations:

Journal of

Transformative

Systemic

Practice

\title{
Re-Membering and Naturing my Life and Work in a Fifth Province
}

\author{
Imelda McCarthy
}

\section{Volume 4}

\section{Issue 1}

\section{Winter 2021}

\section{Keywords:}

colonisation,

EcoSystemic

Return,

Fifth Province,

inequalities,

nature,

systemic practice

\section{Citation Link}

\section{Introduction}

This paper will outline my own systemic journey of engagements and movements in and away from a more natured inclusion in my life and work. Looking back, I can see that from childhood my life was filled with sustainability practices in that I had parents who planted much of our food and never threw away anything that might be useful in the future. In my team, the Fifth Province Associates, one was a farmer's daughter and grew up with a deep knowledge of our countryside and the other was an ecological and climate activist. How had I managed not to put all this together into a more coherent systemic roadmap before now? I thank Roger Duncan (2018) and many of my colleagues here in this issue for reminding me of what I already knew and experienced, and how it could be recycled as it were for a possible more useful future (Simon \& Salter, 2020; Palmer, 2014; Santin, 2020; Triantafillou et al., 2016; Edwards, 2020). They have facilitated me to re-member experiences around nature practices, the possibilities for love and colonisation in our practices, the co-creation of an indigenous Irish therapy practice and my experiences of a deep spiritual practice which I have seen over and over again to foster resilience and equanimity ${ }^{1}$ not only in my own life but also in the lives of clients and those in our Sangha. In the Irish language, the word for resilience, athléimneacht is interesting. Athléimneacht directly translated means jumping (across/in) a ford, an open space or a hollow between two objects. I resonate with this translation as it points to a liminal space so important in Celtic consciousness and of course a fifth province space. Maybe resilience or athléimneacht has been called forth as a need in all of us by the sudden advent, fear and stress of a world in panmorphic crisis (Simon, 2021). 
For a field that is grounded in context, interactions and systems, and given the level of threat our ecosystem is facing, there is no excuse for the field of Family Therapy to not address the ecological context.

(Laszloffy, 2019a, p. 113)

\section{Existence is not human centric}

(Sadguru)

\section{Reflections on the introduction}

We are in a time of "in between" the old world and a world not yet. What do we call it? I call it a Fifth Province - a space between, a liminal space and imaginal space. Some people feel fatigued by postmodernism and modernism which have almost played themselves out in most quarters especially in the face of "fake news" and an "anything goes" for science, truth and common sense on the one hand and the straight jacket of evidence-based practices and tick boxes on the other hand! Jonathan Rowson calls this time, "a time between worlds" and "a time to look within, between and beyond" (2021). So, I am wondering what would spiritual, systemic and co-evolutionary practice look like at this time of panmorphic crisis (Simon, 2021)

I have paid some attention to these meta crises in a previous article (Bateson and McCarthy, 2016) and to spirituality and systemic practice in other publications (for example, 2004, 2010). We are hearing a call to move further in this time of ambiguity where the old leaves its traces and the new offers glimpses. In the systemic field, we have developed first order, second order and third order systems writing about external, reflexive and intersectional systemic matters. The inclusion of the environment, non-human and natural worlds points to a fourth order way of conceptualising systems. While this is important in this time of species decimation and extinction, maybe a "Fifth Order" in systemic thinking and practice is following hot on its heels.

When I think of a murmuration and how birds know when and how to move in synchronisation, in pattern with each other, then I wonder that maybe human beings have the same capacities to intuit each other and move with synergy.

Some of the newer systemic writings (McCarthy and Minogue, 2020; Simon and Salter, 2019, 2021; Simon, 2021; Duncan, 2019) and others in this issue are also addressing some of these kinds of liminal communications and pointing us in the direction of exploring such possibilities. As I write, I also realise that I too am between stories and worlds as I prepare to leave the home I have lived in for 43 years to move to a smaller home more fitted to sustainable downsized living. This witing is emerging out of a liminal space between the re-memberings of a past and the imaginings of a future - between a known world and an unknown world in my personal and professional worlds, together with our larger social and material worlds - surely a Fifth Province! 


\section{The Pandemic}

At the outset of the Pandemic in Ireland when people were only allowed to circulate within two kilometres of their home, it was not unusual to see whole family groups and their animals gathering in little "pods" around our local parks even in early Spring before the weather had warmed the earth or the trees had their leaves. It must have provoked something from ancient times for urban folk to come, en masse, to their local green areas.

I guess this is a little like summer calling us to beaches and rural areas for our holidays. Perhaps, something in the human soul recognises this affiliation with nature with its support of wellbeing in our lives. I know that during the pandemic, in the many therapy and consultation conversations I have, therapists have been advising clients to go walking in their local parks, along canal, riverbanks and seashores. Dublin, being on the coast, many even took to sea swimming which gained momentum throughout the year. Bicycle paths were filled and also added along coastal roads throughout the country while traffic was low to non-existent.

Many around the world rediscovered gardening and growing vegetables again according to newspaper and television reportage. Perhaps this has been a major bulwark for those with access to gardens or allotments in managing depression and anxiety during an almost year and a half of lockdown. Growing flowers, shrubs, trees and vegetables supports us on social, physical, emotional, mental, and spiritual levels if reports from supervisees and clients are anything to go by (for example, Clatworthy et al, 2013). However, as we know only too well, people with gardens are people with some privilege. Many in our communities live on estates and in apartment blocks with no private outdoor gardens or balconies. Many are surrounded by concrete with little or no green spaces or trees. Even in this often taken for granted arena of nature we must not forget that there are massive inequalities in our social living experiences. Our learning often come from the margins and marginalised peoples will always illuminate what we need to address in our ways of living together. My Fifth Province colleagues and I began writing about "marginal illuminations" and colonisation as early as 1989 after visiting the $9^{\text {th }}$ century Book of Kells. (Kearney et al., 1989; Byrne and McCarthy, 2019).

A little virus is surely that part of previously marginalised nature, which has re-introduced humanity to different considerations, values and ethics in their individual, familial and community lives. It seems as we go forward and co-evolve a differently lived life, nature along with other important threatened contexts can no longer be left out of our systemic conversations with those who seek our help in therapy, supervision and consultation. We all matter. We are all matter! Just as we in the North and West of our planet have colonised nature, there is now a growing realisation and calls for realisation of how we have also colonised not only countries of the East and South but also the lives of human beings who are positioned as mattering less than humans in the North and West. This then extends to those peoples' material worlds of non-human animals and the environment that feed and support us. It is surely time to begin to move beyond human centrality in our world(s) (Barad, 2007; Braidotti, 2019). There have been different terms for this decentring of human beings such as metahuman (Chopra, 2019), posthuman (Braidotti, 2019), and Anthropocene (Fremaux, 2019). This is a wake-up call to address not only how human beings continue to colonise the planet but how so-called Free Market Capitalist interests of the North and West foster these destructive activities. As systemic practitioners the time has come for us to step up and develop resilience, critical narratives and coherence in systemic thinking and practice amongst ourselves and our clients. (McCarthy, 2016). 
As I began to think of all these issues, I feel drawn to look over my life and trace the lineage of the growing of my own gendered, political, economic and environmental realisations. I will insert these personal reflections at points throughout this paper.

\section{Growing Realisations}

Since my adolescence I was a kind of activist. Actually, now that I write this article I am called to an earlier instance of that activist impulse being awakened. A month after my only sister was born, my mother brought me with her to the local church one evening. I sat beside her at a side alter with some other women while the priest led a service. I asked why we were not sitting in the centre of the church and what was going on. My mum told me it was because she had just had my baby sister and this was "a blessing of the mother after childbirth" ceremony. My eight-year-old-self thought this a bit strange, so I remember asking her why she needed to be blessed. She explained to me that women were seen as "unclean" during periods and during the child-birth process and then had to be cleansed through a blessing. To this day I can remember the anger and mystification I felt.

The next awakening memory I have is of my sister being in hospital for some stomach pains. My mother had spoken to a social worker (whose notes were kept at the end of the bed in those days). My sister had taken a peek and when I visited, she urged me to look to see what they "said about Mum". What I read was that my mother "was a small fussy woman". I stopped reading and we talked about this not being our Mum and that this social worker didn't know what she was talking about. I made a decision there and then I would never make an "objective" negative opinion in writing about anyone and it was this incident that led to my democratisation of all professional notetaking and not saying anything apart from descriptions of what I had seen with no commentary. I did this in my professional life in memory of my sister whom I lost when she was just on the cusp of her teenage years, to honour my Mum too, and my working-class background. Subsequently many of my own and my team's papers were about the possibility for abuse and colonisation of all clients but more especially those on the margins of society in therapeutic conversations. (McCarthy, 1991, 1994, 2011; McCarthy \& Byrne, 2019).

\section{De-Colonisation: the development of a Fifth Province Approach - Indigenous inter- relationships}

The many recent calls to de-colonial approaches in our lives and work re-minded me of my own start in systemic work. Still early in my career, I had the great fortune and privilege to begin to work with Nollaig Byrne, who was a child psychiatrist, and Philip Kearney, who had also been my classmate as a social science student. We came together shortly after Nollaig and Phil returned to Ireland from the Canada and the USA respectively in 1978 and 1979. When we began set up the first training course in Dublin the field of family and systemic therapies ${ }^{2}$ was mostly populated by North American and British writers. However, as a result some of the ideas and life practices they outlined did not seem resonant with our own context here in Ireland. In fact, in the early development of family therapy in Ireland we 
were not anxious to invite British presenters to give workshops given our relatively recent history of colonisation which officially ended in 1922 with the Irish Republic being declared when I was one year old.

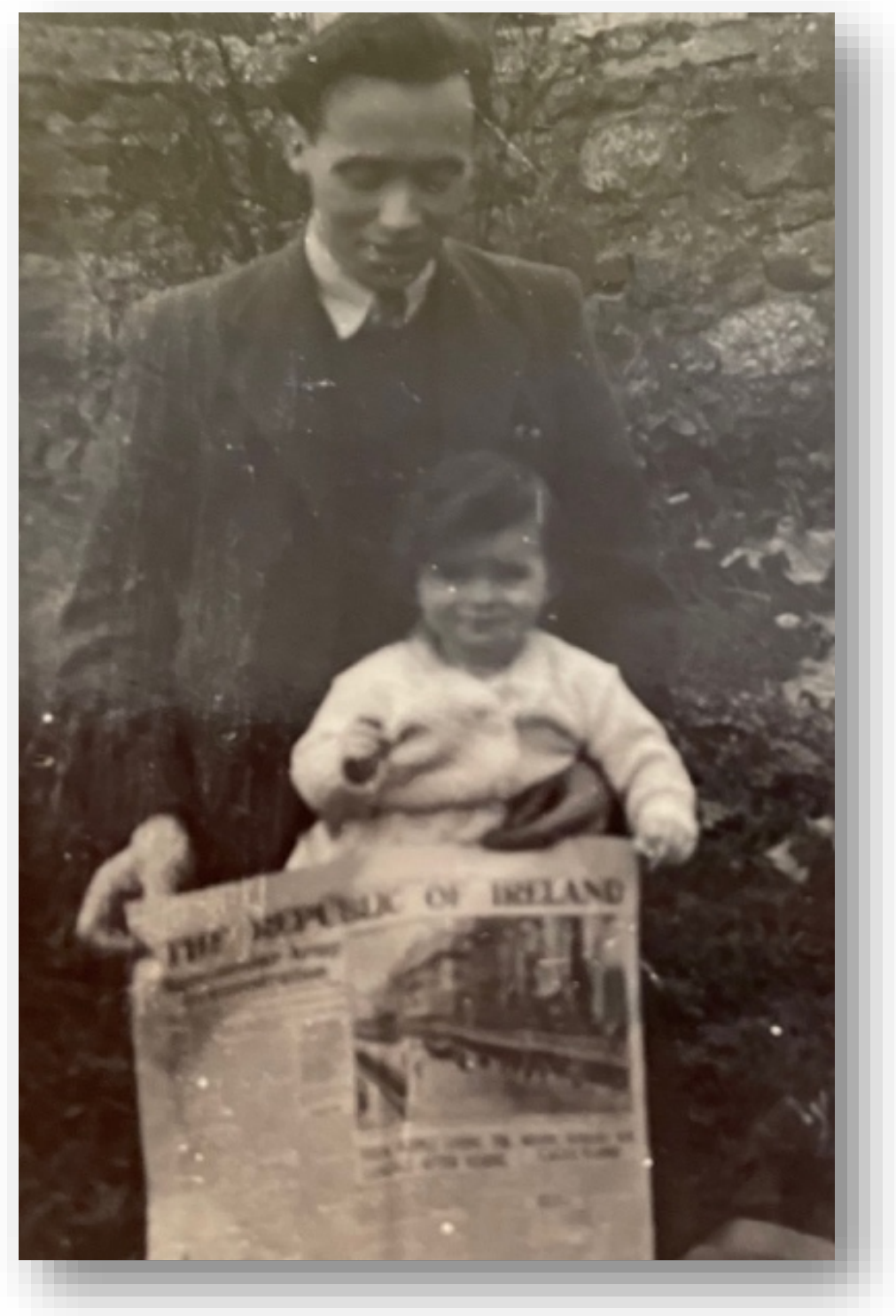

My Dad and I when I was a year old with Newspaper headline declaring the advent of the Republic of Ireland 1949

As we got to know many of our British colleagues our fears were not upheld and many became our great friends and supporters over the years. I am remembering in particular, Peter and Susan Lang, Martin Little of KCC; Alan Cooklin and Gill Gorrell Barnes, Brian Cade, Elsa Jones together with the original team at Cardiff and so on. However, I am skipping ahead of myself as these relationships developed when we had been working for some years together. Initially, we looked to the US for mentors, especially to Monica McGoldrick, Lynn Hoffman and Harry Goolishian. It was Lynn and Monica who introduced us to our systemic colleagues in Europe, especially Gianfranco Cecchin and Luigi Boscolo. In 1983 we had our exciting entry to the "Teams' Conferences" as they came to be 
known, organised initially by Lynn Hoffman around the work of the Milan team. We were also invited by Monica McGoldrick, Carol Anderson and Froma Walsh to join American feminist family therapists for the Women's Colloquia held in a little inn, interestingly called Stonehenge, in Connecticut during the summers of 1984 and 1986. These were later expanded with a further one held in Copenhagen in 1989 and the first gender conference in Oxford in 1991. Much of the impetus for gender work in the systemic field emerged from these meetings. As a result of these meetings, in $1984 \mathrm{I}$ brought a group together in Dublin which we called WITCHES - Women in Therapy Chapter, to explore gender discrimination in our work as family therapists.

Seeing how Irish families were being portrayed in the Anglo-American literature, our team set out to reclaim our indigenous knowledge and practices within our post-colonial Irish society. Countering the Anglo-American hegemony of "authoritative clear communication" we set out to use old Celtic legends and stories (fifth province, children of Lir; ambiguity and ambivalence celebrating the exaggeration of "tall stories" and indigenous story telling)), together with drawing on native 5,000 year old rock carvings for our logo and diamonds and finally calling in the writings of our Irish poets, writers and artists. ${ }^{3}$

Working with Phil, both Nollaig and I were rapidly brought into the world of nature and environmental concerns - whales caught in the ice, global warming as it was then, nuclear power and so on. Phil has been an ecological and environmental campaigner since his early twenties (Kearney 2013). A founding member of the Green Party in Ireland he has gone on to chairing national and international forums on Climate Change and biodiversity. Currently he serves as the national chair of An Taisce which safeguards the heritage of Ireland from Climate Change and environmental issues to archaeology, art and architecture. It was he who brought Nollaig and I to The Crane Bag: Book of Irish Studies (1977) and the rock drawings from the 5,000 year old Neolithic monuments at Newgrange in Co. Meath. It is probably no accident that Meath and West Meath are thought to be part of the Fifth Province, as in the Irish language Midhe (Eng. Meath) means "middle" or "centre". The Fifth Province has been imagined to be an in between space, a liminal space, a space of imagination at the centre of Ireland where long ago the Four Provinces of Ireland met (Hederman and Kearney, 1978)!

Our generation was brought up on Irish stories and we were born into a post-world war two context of scarcity. Although I grew up in Ireland's capital city, Dublin - apart from a year-long sojourn in my mother's rural town and family home, I was very much a city child. My father, like my mother hailed from a small town in rural Ireland. As a young child I saw my parents cut turf and grow their own vegetables. We even had hens in our urban garden. Both my parents were avid gardeners and we always grew our own potatoes, cabbage, onions, lettuce, scallions, peas, tomatoes and rhubarb as the staple crops. Of course, I was inducted into this production from a very early age until in my teens when peer company and roaming the roads of our locality became a much more interesting activity for me. My best friend, Clarice, whose parents also had an allotment beside my family's, was my partner in these forays away from our early experiences of cultivating vegetables.

Although I grew up with an appreciation of food production and the nature of canal bank life I had no sense of nature as part of who I was. I saw myself as a separate being. You'd have thought being part of a hockey team for most of my life would have taught me something about connections, being a part of something bigger. Then when I did find Systems Theory as a trainee social worker, I did not understand it and got a glorious $10 \%$ in my first test. Later, in the same course, I discovered the work of Salvador Minuchin and his team's work with poor inner-city children and their families and the light 
bulb finally came on.(Minuchin et al., 1967). Here, he worked with Braulio Montalvo and Bernice Rossman who both went on to work at the Philadelphia Child Guidance Clinic with him when he was made Clinical Director. Dick Auerswald, who also worked with them, was the first to use the term Eco Systemic Family Therapy (1968). Because of the resonance of this work with my own in a high-rise public housing area I went on to have the great privilege of being supervised by Braulio Montalvo in Philadelphia in the late 70's and again at the Philadelphia Child Guidance Clinic during the summer of 1981. In this I period, I experienced all the ways in which a family and community focused clinic fostered resilience through their in-service and community outreach programmes.

\section{Fostering Resilience and Equanimity}

Fostering resilience and equanimity has been a pre-occupation of mine for as long as I can remember. The concept probably even brought me into the therapy field and so my Philadelphia experiences helped augment the ways I could support families in crises. Of late it has become stronger as I began to look for all the ways in which we can as systemic practitioners draw attention to this time of what Gail Simon refers to as "panmorphic crisis" (Simon 2021). Our world and our humanity are in trouble and it is probably true to say that the majority on the northern part of our planet are still unaware of the degree and range of crises looming before us if we do not cut our emissions, roll back climate change and cease other destructive environmental activities.

As a systemic practitioner the following are some of my ideas in relation to the fostering of resilience in all of us and so may be useful conversational areas in our work and lives moving forward. As an illustration of such resilience, I love the images above taken by a Traditional Chinese Medical Practitioner, Sabine Wilms of mushroom spores on a metal surface. What incredible resiliency in these underground and above ground mycelium networks. These little mushrooms can teach us so much about interconnection and survival ( see the film, Fantastic Fungi, 2019).
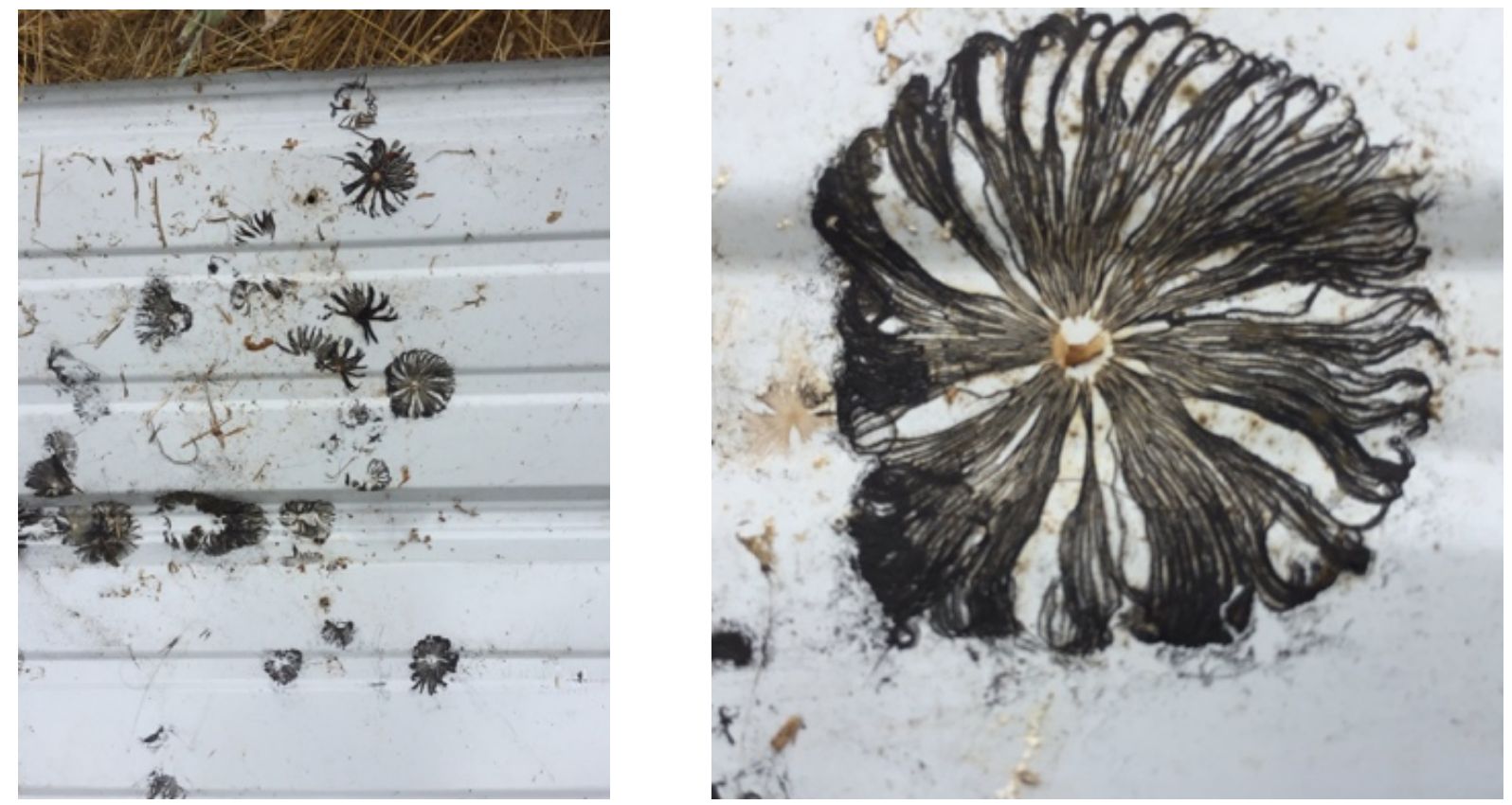

"The aching beauty of impermanence" Mushroom spores on metal covering of compost heap.

Photos by Sabine Wilms, 2021 
If I think of my own situation when I had a full hip replacement my husband had set up a space in our "garden" room where I could see the sky and clouds through the skylight windows in the ceiling. I was surrounded by glass with large doors onto our patio which allowed fresh air to circulate throughout my days. I slept and spent my days in this nature idyll in my home. Here the trees, shrubs and flowers together with the birds and the bees (and other insects) moved freely in and out of the space. Each day in this space I felt the improvement - in pain, mobility, flexibility and energy. I had no doubt about it at the time and was aware that my rehabilitation was being supported by the nature around me as it interconnected and intra-connected with the nature that was also my own self. I was of course supported daily by my husband, Michael and my wonderful friend, Jean.

Reflecting thus on my experiences of rehabilitation and healing in a nature-saturated urban environment brought me back to my childhood home on the banks of one of Dublin's canals. I grew up on a small ordinary road of Edwardian red-bricks. At one end of our road was the Grand Canal while at the other end was the art deco cigarette factory with its constant aroma of tobacco filling the air!! However, at the rear of our houses beyond our back gardens, there was "the lane" as we called it. This space was grassed and full of trees of different kinds including the haw trees which feature large in Irish mythological stories of the Sí (fairies). Here we made imaginary worlds to occupy and climbed high into the trees often to the consternation of our onlooking parents. Here was a little bit of countryside experience in the heart of the city of my childhood.

When I began to work at the Mater Clinic during the 1970's and 80's, staff members in Social Work and Psychology brought their dogs to work in their clinical sessions. There was a programme of equine therapy for children in a school for autistic children; there were rabbits and fish for the children to interact with in the waiting room. None of these activities I imagine would now pass insurance, health and safety concerns in spite of learning that, "Animals can be a wonderful addition to therapeutic intervention, not only to help decrease symptomatology, but also in creating a sense of safety and positivity for some clinical participants" (Hertlein and Hechter, 2019). Then, there were also the Summer Schools for children and adolescents which included hikes and camping trips to the sea and in the mountains. Today's children and young adults maybe the first generations in our Western world, to be so disconnected from nature (Hechter and Fife, p. 19). Irish Philosopher, Richard Kearney in his latest book talks about the plight of modern children and indeed their parents in being out of touch in relationships and in their social worlds because they are so caught up in the "touch screens" of their digital worlds (Kearney, 2021).

\section{Reflecting on an inter-/intra-connected Nature}

Along with my friends and colleagues (Chris Kinman, 2016; Gail Simon, 2021; Nora Bateson, 2016; Roger Duncan, 2019; Chiara Santin, 2020) who have been writing about "naturing therapies", Anne Fremaux in her book, "Green Republicanism" (2019) re-embeds humans and economics within the natural world as part of it, shows how to repair social and ecological connectivities, how to restore our relationships with non-human animals and she challenges "endless growth" models of consumption. Perhaps she is proposing a new republic of the human and natural environment beyond commodification of the living and natural world of which we are a part. (Fishwick \& Kiersey, 2021). In fact, Fremaux calls us to the co-creation of sustainable and resilient societies to bring us into a post Anthropocene world where non-humans and humans can flourish (2019). 
Over the years in my practice, I have been having conversations with clients and supervisees about resilience and wellbeing in their lives. The conversations have been both clinical in orientation and knitted into their relational and individual wellbeing. These have included considerations of fostering resilience in children through recycling, single plastic use, our changing world-scape, future shortages and how they might acquire knowledge of food growing and repairing toys and so on alongside their parents, as well as walking in nature, walking barefoot on the earth, gardening, perma-cultural activities, meditation practices and retreats.

Before the pandemic I had been organising weekend retreats. The activities integrated systemic and Fifth Province practices with the teachings of my spiritual teacher, Sri Vasudeva. Through these we have developed a meditative way of speaking in a practice we called, "Sacred Conversations". The latter was taken from Fifth Province Systemic practice and one that we also shared with the Just Therapy Team in New Zealand (Waldegrave et al., 2003). In these retreats we chanted, meditated, held sacred conversations, reflected during individual quiet time and walked in woodlands. We have tried where possible to bring the group to areas of woodland to walk and often used these walks to commune with nature or to reflect on some spiritual inspirations while in nature. In a way, my own journeys into the wildness of my inner being began through meditation and during four- and five-day solo retreats in the countryside. Meditation has enabled me to experience greater synergy and synchronicity in my life in that I could see intra-connections in my daily life vividly. Those around me were noticing a growing calmness and equanimity which I also felt.

It has been my own experience that practices that start with our inner world help build equanimity in our inner and outer lives. This switch in focus to including the inner world of multi-dimensional experiencing was brought about when Sri Vasudeva, commented after a presentation on conversations around sexualised abuse (Wade 1997) that my "frame was too small". As I was thinking within a solution-focused frame, I had begun my presentation with a problem definition of the work, child and family. He, on the other hand, was inviting me to move from a spiritual space were there were no problems, where, as Gianfranco Cecchin often said, "everything is perfect" (1984, personal communication). Immediately, the penny dropped as I also re-membered Gianfranco's communication. Moving from a context of spirit the field was more expansive and the problem became smaller and secondary by existing in or emerging from that field as a description of a facet of life. As Shakespeare in Hamlet, Act 2, Scene 2 said, "nothing is good or bad but thinking makes it so"! I had also seen from my direct experience of Allan Wade's work on Response Based Therapy that in moving from expansive possibilities, greater resilience emerged in, I would say, both clients and therapists (Wade, 1997, 2007). I have found this has been especially so in the wake and face of crises, tragic events and challenging life issues.

I use the phrase "inner world" in a way that both calls us inward in our own unique expression as an individual human being and inwards within the intra-connectivity of us with our universe. It has been my experience that as I connect with the essence of who I am in stillness and silence, I also powerfully connect with the essence of who we are as in inter- and intra-connected whole or web. This has been more augmented when we do this together in groups. In these activities we come to experience and "see" that we are indeed inseparable from each other, nature and our material world. There is interbeing. In this inter-being, we inter-are (McCarthy, 2004, 2016; Hahn, 1999)! As Julian of Norwich, the fourteenth century mystic and anchorite has said, there is just a "onening" throughout all of nature, divine, human and non-human (Fox, 2020). Perhaps, in these changing times of the pandemic this is surely a time for greater "oneing" which can bring forth experiences of resilience and equanimity. 
As long as our lives are more commerce than communion, more product than process, more us/them than we, more manufactured than organic, and more digital reality than nature reality, the more likely we will be to rely on secondary instead of primary sources to try and satisfy primary needs.

(Laszloffy, 2019b, p. 39)

We could say that we are in a time between dystopia and utopia, in a time between worlds, that we are in a liminal space. And we might say that we are in a time between stories. While recognising our current world and ecological predicaments, we are also in great need of a new story of hope for the future despite the inevitability of facing more of the environmental challenges and fighting social injustice (Afuape and Hughes, 2016). We will need to be able settle well with less as we support each other towards a different kind of wellbeing, athléimneacht on a New Earth (Tolle, 2009). This is surely what systemic practitioners can play a part in?

\section{Acknowledgements}

Thank you to Phil Kearney and Nollaig Byrne for reading the article and for their useful suggestions.

\section{Footnotes}

1. In Buddhism, equanimity is one of the four sublime attitudes and is considered: neither a thought nor an emotion, it is rather the steady conscious realisation of reality's transience. It is the ground for wisdom and freedom and the protector of compassion and love. It is an experience of not being tossed about in the midst of life's challenges where we have mental and emotional stability under strain or tension. It is often referred to as equilibrium, tranquillity or calmness.

2. The first clinical training course in Family Therapy was founded at the Department of child and Family Psychiatry, Mater Misericordiae Hospital, Dublin by Dr Nollaig Byrne, Phil Kearney, Myself and Professor Jim Sheehan and was under the auspices of the Clinical Director and Administrator of the Clinic, Dr Paul McQuaid and Sr. Jo Kennedy

3. I recognise other indigenous therapy emergences in Europe from the 1980's and 1990s - Milan Systemic Therapy in line with a more community approach in Italy; The Reflecting Team in the North of Norway with Tom Andersen and his team; Open Dialogues in the North of Finland with Jaakko Seikkula and his teams and so on.

4. Where possible in the reference list I have used the chosen first names of authors.

\section{References}

Afuape, Taiwo \& Hughes, Gillian (2016). Liberation Practices: Towards emotional wellbeing through dialogue. London: Routledge.

Auerswald, Edgar H. (1968). Interdisciplinary versus Ecological Approach. Family Process, 7(2), 202 - 215. https://doi.org/10.1111/j.1545-5300.1968.00202.x

Barad, Karen (2007). Meeting the Universe Halfway: Quantum physics and the entanglement of matter and meaning. Durham, NC: Duke University Press.

Bateson, Nora (2016). Small Arcs of Larger Circles: framing through other patterns. Axminster: Triarchy Press. 
Bateson, Nora \& McCarthy, Imelda (2014). An Ecology of Mind: Family Therapy in the face of new emerging conditions. Human Systems Journal of Systemic Therapy, 23, 4-16.

Braidotti, Rosi (2019). Post Human Knowledge. Cambridge, UK: Polity Press.

Braverman, Lois (1988). A Guide to Feminist Family Therapy. New York: Haworth Press.

Byrne, Nollaig O'Reilly \& McGuirk, Myra (1994). Just now I like to call myself Myra. In McCarthy, Imelda C. (Ed.) Poverty and Social Exclusion, special issue of Human Systems: Journal of Systemic Consultation and Management, 5(3/4), $155-168$.

Cecchin, Gianfranco (1994). Personal communication.

Chopra, Deepak (2019). Metahuman: Unleashing your infinite potential. New York: Penguin Books.

Clatworthy, Jane; Hinds, Joe \& Camic, Paul M. (2013). "Gardening as a mental health intervention: A review". Mental Health Review Journal, 18(4), 214-225. https://doi.org/10.1108/MHRJ-02-2013-0007

Coates, John (2003). Ecology and social work toward a new paradigm. Black Point, NS: Fernwood Publishing. Duncan, Roger (2019). Mind in Nature: Systemic Thinking and Imagination in Ecopsychology and Mental Health. Oxford \& New York: Routledge.

Edwards, Lorna (2020). Absent friends in shared landscapes .... Murmurations: Journal of Transformative Systemic Practice, special issue: Pandemic as Systemic Flux, 3(1). https://doi.org/10.28963/3.1.11

Fishwick, Adam \& Kiersey, Nicholas (2021). Post-Capitalist Futures: Political economy beyond crisis and hope. London: Pluto Press.

Fox, Matthew (2020). Julian of Norwich: Wisdom in a Time of Pandemic - and Beyond. Foreword by Mirabai Starr. Bloomington, IN: iUniverse.

Fremaux, Anne (2019). After the Anthropocene: Green Republicanism in a Post-capitalist World (Environmental Politics and Theory). London: Palgrave Macmillan.

Hanh, Thich Nhat (1999). Going Home: Jesus and Buddha as Brothers. London: Rider.

Hechter, Sarah, A. \& Fife, Stephen (2019). Children and Nature. In Laszloffy, Tracey, A. \& Twist, Markie, L.C. Eco-Informed Practice: Family Therapy in an Age of Ecological Peril. Cham, Switzerland: AFTA/Springer.

Hederman, Mark. P. \& Kearney, Richard (1977). The Crane Bag: Book of Irish Studies 1(1).

Hertlein, Katherine, M. \& Hechter, Sarah, A. (2019). Clinical Applications of an Eco-Informed approach to therapy: A systemic perspective. In Laszloffy, Tracey, A. \& Twist, Markie, L. C., Eco-Informed Practice: Family Therapy in an Age of Ecological Peril, pp 59-72. Cham, Switzerland: AFTA/Springer.

Jones, Elsa (1994). Gender and Poverty as Contexts for Depression. In McCarthy, Imelda C. (Ed.) Special Issue on Poverty and Social Exclusion, Human Systems: The Journal of Systemic Consultation and Management. 5, $169-183$.

Kearney, Philip. A.; Byrne, Nollaig. O'Reilly \& McCarthy, Imelda. C. (1989). Just Metaphors: Marginal Illuminations in a Colonial Retreat. Family Therapy Case Studies, 4, 17 - 31.

Kearney, Philip (2013). The Systemic Crisis of Climate Change: Clinical and Political reflections. Feedback: Journal of Family Therapy Association of Ireland, 1, 42 - 50.

Kearney, Richard (2021). Touch: Recovering our most vital sense. New York: Columbia University Press. Kennedy, Jo \& Gibson, Rebecca (1998). Women and Violence. Feedback: Journal of Family Therapy Association of Ireland, 8(2), $10-17$.

Kennedy, Jo \& O’Shaughnessy Marie (1998). Political Conversations; Evolving Team Reflections. Feedback: Journal of Family Therapy Association of Ireland, 8(2), 18 - 19.

Kinman, Christopher (2016). The Event: on experimenting with complex systems. In McCarthy, Imelda \& Simon, Gail (Eds.), Systemic Therapy as Transformative Practice. Farnhill: Everything is Connected Press. 
Laszloffy, Tracey, A. (2019a) Family Therapy and Eco-Activism. In Laszloffy, Tracey, A. \& Twist, Markie, L. C., Eco-Informed Practice: Family Therapy in an Age of Ecological Peril. Cham, Switzerland: AFTA/Springer.

Laszloffy, Tracey, A. (2019b). What is an Eco-Informed Approach to Family Therapy. In Laszloffy, Tracey, A. \& Twist, Markie, L.C., Eco-Informed Practice: Family Therapy in an Age of Ecological Peril, pp 7-20. Cham, Switzerland: AFTA/Springer.

Laszloffy, Tracey, A. (2019c). Evaluating how mental, physical and relational health are tied to ecological issues". In Laszloffy, Tracey, A. \& Twist, Markie, L. C., Eco-Informed Practice: Family Therapy in an Age of Ecological Peril. Cham, Switzerland: AFTA/Springer.

McCarthy, Imelda C. (1991). Colonial Sentences and Just Subversions: The Potential for Love and Abuse in Therapeutic Encounters. Feedback: Journal of Family Therapy Association of Ireland, 3, 3 - 7.

McCarthy, Imelda C. (1994). Serving those in Poverty: A Benevolent Colonisation? Keynote presentation. European Family Therapy Association Conference. Amsterdam.

McCarthy, Imelda C. (Ed.) (1994a). Special Issue on Poverty and Social Exclusion, Human Systems: The Journal of Systemic Consultation and Management, 5.

McCarthy, Imelda C. (2001). Fifth Province re-versings: the social construction of women lone parents' inequality and poverty. Journal of Family Therapy, 23(3), 253 - 277. https://doi.org/10.1111/1467-6427.00183

McCarthy, Imelda C. (2004). The Fifth Province and Spirituality: Co-Creating a sacred space of love in therapy conversations. In (Ed.) Madigan, Stephen. Therapy from the Outside In. Vancouver, BC: Yaletown Family therapy.

McCarthy, Imelda C. (2010). The Fifth Province: Imagining a Space of Dialogical Co-Creations . Context. December, 6-11.

McCarthy, Imelda. C. (2011). Abusing Norms: Welfare Families and Professional Intervention. Human Systems: The Journal of Systemic Consultation and Management, 22, 339 - 350 (also 1994).

McCarthy, Imelda C. (2016). The Ocean in the Waves: Unity in Diversity and the implications of a Fifth Province Approach in complex systems. http://metalogos-systemic-therapy-journal.gr, 31.

McCarthy, Imelda C. and Minogue, Jean (2019). The Fifth Province Approach as a Systemic Meditative Practice. Murmurations: Journal of Transformative Systemic Practice. 2(2), 55 - 69. https://doi.org/10.28963/2.2.6

McCarthy, Imelda C. and Byrne, Nollaig O'Reilly (2019). A Fifth Province Approach to Intracultural Issues in an Irish Context: Marginal Illuminations. In McGoldrick, Monica \& Hardy, Kenneth. Re-Visioning Family Therapy. ( $3^{\text {rd }}$ edition). New York: Guilford.

Minuchin, Salvador; Montalvo, Braulio; Guerney, Bernard, G. Jnr; Rosman, Bernice, L. \& Schumer, Florence, E. (1967). Families of the Slums. New York: Basic Books.

Trianatafillou, Fani; Pouliopoulou, Dimintra; Bethymouti, Elektra \& Moureli, Efrossini (2016). The Inner and Outer Sides of the Wind: Collaborative practice in the solidarity Social Medical Centre of Thessaloniki, Greece. In McCarthy, I \& Simon, G. (Eds.), Systemic Therapy as Transformative Practice. Farnhill: Everything is Connected Press.

O’Sullivan, Bernadette (2010). On Being Willing Apprentices. Feedback: Journal of the Family Therapy Association of Ireland, 12, 4 - 15.

Palmer, Hugh (2014). Steps towards fourfold vision: From the myth of power to a cybernetic unity of healing. Context.

Santin, Chiara (2020). The Power of Context(s). Pandemic as Systemic Flux. https://systemicflux.com/2021/01/24/the-power-of-contexts/

Simon, Gail (2021). Panmorphic Crisis: Cultural rupture and systemic change. Feedback: Journal of the Family Therapy Association of Ireland, Summer, 17 - 32. 
Simon, Gail \& Salter, Leah (2019). Transmaterial Worlding: Beyond Human Systems. Murmurations: Journal of Transformative Systemic Practice, 2(2), 1-17. https://doi.org/10.28963/2.2.2

Simon, Gail \& Salter, Leah (2020). Transmaterial Worlding as Inquiry. In The Sage Handbook of Social Constructionist Practice. Eds. Sheila McNamee, Mary Gergen, Celiane Camargo-Borges, \& Emerson F. Rasera. London: Sage Publications.

Tolle, Eckhart (2009). A New Earth: Create a better life. UK: Penquin

Trianatafillou, Fani; Pouliopoulou, Dimintra; Bethymouti, Elektra \& Moureli, Efrossini (2016). The Inner and Outer Sides of the Wind: Collaborative practice in the solidarity Social Medical Centre of Thessaloniki, Greece. In McCarthy, I. \& Simon, G. (Eds.), Systemic Therapy as Transformative Practice. Farnhill: Everything is Connected Press.

Wade, Allan (1997). Small Acts of Living: Everyday Resistance to Violence and Other Forms of Oppression. Journal of Contemporary Family Therapy, 19(1), 23-39.

Wade, Allan (2007). Despair, Resistance and Hope: Response-based therapy with victims of violence. In (Eds.) Flaskas, C.; McCarthy, I. \& Sheehan, J., Hope and Despair in Narrative and Family Therapy: Adversity, Reconciliation and Forgiveness. Hove/New York: Brunner/Routledge.

Waldegrave, Charles; Tamasese, Kiwi; Tuhaka, Flora \& Campbell, Warihi (2003). Just Therapy - a journey: Collection of papers from the Just Therapy team New Zealand. Adelaide: Dulwich Centre Publications.

\section{Author}

Imelda McCarthy, PhD, has been in the Family Therapy and Systemic field for most of her life as a therapist, trainer and supervisor. She was also an academic in the social sciences over twenty-five years at University College Dublin. She has published and presented internationally since 1983 and her work has been translated into nine languages. Over the last twenty years, Imelda has led a meditation group in her home in Dublin. She was spiritual director of a meditation organisation (Blue Star Ireland) for many years and is a member of Spiritual Directors International (SDI).

URL: https://imeldamccarthy.com

Email: imeldamccarthy46@gmail.com

\section{Citation}

McCarthy, Imelda C. (2021). Re-Membering and Naturing my Life and Work in a Fifth Province. Murmurations: Journal of Transformative Systemic Practice, 4(1), 74-86. https://doi.org/10.28963/4.1.6 